\title{
Adaptation Trail of Garlic (Allium sativum L.) Varieties in the High Land of Eastern Hararghe Zone, Oromia, Ethiopia
}

\author{
Email address: \\ mammejafar@gmail.com (M. Jafar) \\ ${ }^{*}$ Corresponding author
}

Mohammed Jafar*, Gezu Degefa, Girma Wakgari, Gebisa Benti

Department of Horticulture, Fedis Agricultural Research Center, Harar, Ethiopia

\section{To cite this article:}

Mohammed Jafar, Gezu Degefa, Girma Wakgari, Gebisa Benti. Adaptation Trail of Garlic (Allium sativum L.) Varieties in the High Land of Eastern Hararghe Zone, Oromia, Ethiopia. American Journal of Life Sciences. Vol. 9, No. 1, 2021, pp. 7-10. doi: 10.11648/j.ajls.20210901.12

Received: January 1, 2021; Accepted: January 13, 2021; Published: January 30, 2021

\begin{abstract}
Garlic (Allium sativum L.) belongs to the family Alliaceae and is the second most widely used Allium next to onion. Eastern Hararghe has a considerable potential agro ecology which is suitable for garlic production. However, lack of improved and adaptable varieties of this crop is the major production constraints to study area. A field experiment was conducted for two consecutive years (2019 and 20120) during the cropping season on farmers' land at Kombolcha and Gursum districts. The objective of the study was to identify adaptable, high yielding and diseases tolerant garlic varieties for study area and similar agro ecology. The treatments arranged in randomized complete block design with three replications. The treatments were consisted of five garlic varieties (Chelenko I, Kuriftu, Tsedey 92, HL and Chefe) and one local check. The result of the study showed significant differences among varieties for all the recorded traits except days to maturity. Among the varieties, Tsedey 92 provided about $54.3 \%$ and $13.3 \%$ yield advantages over the local and standard check, respectively. Also Tsedey 92 was tolerant to rust disease than other varieties and local cultivar. Therefore, for sustainable garlic production and productivity in study area Tsedey 92 was recommended and need to be demonstrated.
\end{abstract}

Keywords: Adaptation, Bulb Yield, Diseases, Garlic, Varieties

\section{Introduction}

Garlic (Allium sativum L.) belongs to the family Alliaceae and is the second most widely used Allium next to onion [14]. Garlic is among the most important bulb vegetable crops used as a seasoning or condiment of foods because of its pungent flavor. Garlic adds a taste to foods as well as helps to make them more palatable and digestible [7]. Garlic has higher nutritive value than other bulb crops in addition to containing antibiotics like garlicin and allistatin [9]. In Ethiopia, the area coverage of garlic during the 2017/18 main cropping season was $19,412.49$ ha, and total production was about $178,22.19$ tonnes with an average productivity of $9.1 \mathrm{t} \mathrm{ha}^{-1}$ [2]. This far below the world average yield of $16.71 \mathrm{t} \mathrm{ha}^{-1} \mathrm{tha}^{-1}$ [3] and neighboring country like Egypt produced 309,155 tonnes with productivity of $24.34 \mathrm{t} / \mathrm{ha}$ [4]. The low yield of this crop due to many biotic and abiotic factors such as lack of high yielding varieties, non-availability of quality seeds, imbalanced fertilizer use, lack of irrigation facilities, lack of proper disease and insect pest management and other agronomic practices, low storability, and lack of proper marketing facilities [5, 11]. Eastern Hararghe has a great potential to produce garlic under rain fed and irrigation. However, due to lack of improved and adaptable garlic varieties with their improved agronomic practices the farmers use only the local cultivar with their own traditional production. Even if the area is very suitable and the crop is very important commercially, farmer's income generation from garlic and productivity is still unsatisfactory. There are no any research efforts made in relation to adaptability of garlic varieties in study area. Therefore, objective of this study was to identify adaptable, high yielding and diseases tolerant garlic varieties for study area and similar agro ecology.

\section{Materials and Methods}

\subsection{Description of Experimental Site}

The experiment was conducted under rain fed for two 
consecutive years (2019 and 2020) at Kombolcha and Gursum districts on farmers' land, Eastern Hararghe zone, Oromia region state, Ethiopia. Kombolcha is located at 17 $\mathrm{km}$ far away from Harar town. The altitude of district ranges from 1200 to 2460 meters above sea level. The district receives a mean annual rainfall of $600-900 \mathrm{~mm}$, which is bimodal and erratic in distribution. The small rainy season starts in February/March and extends to mid-May, while the main rainy season stretches between July and August. The mean annual minimum and maximum temperatures are 13.8 and $24.4^{\circ} \mathrm{C}$, respectively [8]. Gursum is located at $75 \mathrm{~km}$ far away from Harar town. The altitude of the district ranges from 1200 to $2938 \mathrm{~m}$ above sea level with the annual rain fall of 650 to $750 \mathrm{~mm}$ and the mean annual minimum and maximum temperature of 18 and $25^{\circ} \mathrm{C}$, respectively. The area has short rainy season March to April and long rainy season June to August [13]

\subsection{Experimental Materials}

Table 1. Description of five garlic varieties and one local check selected for the trial.

\begin{tabular}{llll}
\hline No & Varieties & Year of released & Breeder/Maintainer \\
\hline 1 & Chefe & 2015 & Debre Zeit Agricultural Research center \\
2 & Kuriftu & 2010 & Debre Zeit Agricultural Research center \\
3 & Tsedey 92 & 1999 & Debre Zeit Agricultural Research center \\
4 & Holeta & 2015 & Debre Zeit Agricultural Research center \\
5 & Chelenko I(Standard check) & 2014 & Haramaya University \\
6 & Local & - & Farmers of study area \\
\hline
\end{tabular}

Source $=$ Ministry of Agriculture and Natural Resources (10)

\subsection{Treatments and Experimental Design}

The treatments were consisted of five garlic varieties and one local check (Table 1). The trial was carried out in randomized complete block design (RCBD) having three replicates in a gross plot size of $3.6 \mathrm{~m}^{2}(1.8 \mathrm{~m}$ and $2 \mathrm{~m})$ with a spacing of $1 \mathrm{~m}$ between replicates and $0.5 \mathrm{~m}$ between plots. All treatments were assigned randomly to the experimental plots. The experimental field was prepared following the conventional tillage practice using oxen plow. Cloves of medium sized (2 -3 g) were planted by hand in rows $30 \mathrm{~cm}$ apart and with $10 \mathrm{~cm}$ between plants with in rows. $\mathrm{N}$ was split applied in the form of Urea half at planting and the other half at 30 days after planting while all the NPS was applied at time of planting.

\subsection{Data Collection}

Data were recorded on plant height, leaves length, bulb diameter, number of cloves per bulb and bulb weight from a sample of 10 representative plants while days to maturity and bulb yield ware collected on plot base. Also disease data were collected by scale (1 to 5).

\subsection{Data Analysis}

Analysis of variance were carried out using GenStat discovery $15^{\text {th }}$ edition software for the parameters studied following the standard procedures [6]. Means that showed significant difference were compared using Least Significant Difference (LSD) test at 5\% significant level.

\section{Results and Discussion}

Combined analysis of variance showed the presence of highly significant $(\mathrm{P} \leq 0.01)$ differences among the varieties for the plant height, number of cloves per plant, bulb diameter and yield; significant difference $(\mathrm{P} \leq 0.05)$ for leave length and bulb weight. The presence of significant differences among varieties indicates the presence of genetic variability for each of the characters among the tested varieties. There was also highly significant $(\mathrm{P} \leq 0.01)$ differences among treatments for maturity date; significant difference $(\mathrm{P} \leq 0.05)$ for plant height due to the environmental variation. Only bulb weight was significant $(\mathrm{P} \leq 0.05)$ differences among treatments due to the Genetic-environment interaction.

Table 2. The mean squares for different sources of variation and the corresponding $C V(\%)$ for parameter studied.

\begin{tabular}{lllllllll}
\hline S V & DF & PH & DM & LL & NCPB & BD & BW & BY \\
\hline Rep & 2 & 14.73 & 0.26 & 32.62 & 0.306 & 0.53 & 35.97 & 81.79 \\
Variety & 5 & $244.44^{* *}$ & 4.88 & $68.84^{*}$ & $26.8^{* *}$ & $202.8^{* *}$ & $120.54^{*}$ & $2939.78^{* *}$ \\
Environment & 1 & $206.72^{*}$ & $2900.7^{* *}$ & 53.13 & 0.038 & 94.35 & 117.86 & 172.33 \\
V ${ }^{\text {E }}$ & 5 & 37.69 & 9.41 & 4.41 & 2.095 & 12.71 & $39.8^{*}$ & 133.45 \\
Error & 58 & 50.96 & 66.1 & 21.47 & 4.102 & 15 & 49.99 & 90.08 \\
Total & 71 & & & & & & 3.9 & 15 \\
CV $(5 \%)$ & & 14.7 & 5.8 & 13.8 & 19.6 & 15.4 & 33.9 & \\
\hline
\end{tabular}

Keys: *,*: significant at $5 \%$ and $1 \%$ respectively, $\mathrm{S} . \mathrm{V}=$ source of variation, $\mathrm{E}=$ environment, $\mathrm{V} * \mathrm{E}=\mathrm{variety}$ verses environment, $\mathrm{CV}=$ coefficient of variation, $\mathrm{DF}=$ degree of freedom $\mathrm{DM}=$ days to maturity, $\mathrm{PH}=$ plant height, $\mathrm{LL}=$ leaf length, $\mathrm{NCPB}=$ number of clove per bulb, $\mathrm{BD}=$ bulb diameter, $\mathrm{BW}=$ bulb weight, $\mathrm{BY}=$ bulb yield 
Table 3. Combined mean of yield and yield parameters of garlic varieties over years and locations.

\begin{tabular}{|c|c|c|c|c|c|c|c|c|}
\hline Varieties & DM & PH(cm) & $\mathbf{L L}(\mathbf{c m})$ & $\mathrm{BD}(\mathrm{mm})$ & NCPB & BW(g) & BY(t/ha) & RDS \\
\hline Tsedey 92 & 140.4 & $48.98 b$ & $35.44 \mathrm{ab}$ & $31.20 \mathrm{a}$ & $10.08 \mathrm{~b}$ & $26.18 \mathrm{a}$ & $8.45 a$ & 1 \\
\hline Chelenko I & 139.9 & $55.29 a$ & $36.51 \mathrm{a}$ & $27.46 b$ & $10.17 \mathrm{~b}$ & $22.50 \mathrm{ab}$ & $7.46 b$ & 2 \\
\hline Kuriftu & 140 & $46.9 \mathrm{bc}$ & $31.54 b$ & $26.72 b$ & $11.11 b$ & $20.98 \mathrm{ab}$ & $7.00 \mathrm{~b}$ & 2 \\
\hline Chafe & 139.6 & $46.02 b c$ & $31.32 \mathrm{~b}$ & $25.16 b c$ & $9.47 b c$ & $18.96 \mathrm{~b}$ & $5.17 \mathrm{c}$ & 3 \\
\hline Local & 140.1 & $51.52 \mathrm{ab}$ & $35.28 \mathrm{ab}$ & $22.98 \mathrm{c}$ & $12.75 \mathrm{a}$ & $19.54 b$ & $5.47 \mathrm{c}$ & 3 \\
\hline $\mathrm{HL}$ & 138.6 & $42.37 \mathrm{c}$ & $31.47 \mathrm{~b}$ & $23.37 \mathrm{c}$ & $8.36 \mathrm{c}$ & $17.14 b$ & $4.34 \mathrm{~d}$ & 4 \\
\hline CV $(\%)$ & 7.4 & 14.9 & 13.5 & 12.7 & 19.1 & 33.9 & 15.4 & \\
\hline
\end{tabular}

Keys: NS $=$ Not significant, $C V=$ Coefficient of Variation, LSD $=$ Least Significant Difference. Means followed by different letters within columns are significantly different by Duncan's new multiple range test $(\mathrm{P}=0.05)$. $\mathrm{DM}=$ days to maturity, $\mathrm{PH}=\mathrm{plant}$ height, $\mathrm{LL}=$ leaf length, $\mathrm{NCPB}=$ number of clove per bulb, $\mathrm{BD}=$ bulb diameter, $\mathrm{BW}=$ bulb weight, $\mathrm{BY}=$ bulb yield, $\mathrm{RDS}=$ Rust disease score (1-5)

\subsection{Maturity Date}

The current result showed that there was no significance difference among varieties, but HL variety was early matured (138.6 day) followed by Chafe (139.6) while Tsedey 92 variety was late maturity date(140.4 days ) compared to other varieties and local.

\subsection{Plant Height and Leaf Length}

The current study revealed that the type of variety affected the plant height and leaf length. The highest plant height $(55.29 \mathrm{~cm})$ was recorded from Chelenko I followed by local $(51.52 \mathrm{~cm})$ and Tsedey $(48.98 \mathrm{~cm})$ while the lowest plant height $(42.37 \mathrm{~cm})$ was recorded from HL. On the other hand, a significant the highest leaf length $(36.51 \mathrm{~cm})$ was recorded from Chelenko I followed by Tsedey $(35.44 \mathrm{~cm})$ and local check (35.28a) while the lowest leaf length was recorded from Chefe variety $(31.32 \mathrm{~cm})$. In contrast to current finding research reported that the highest pseudo stem length was recorded from local cultivar $(28.80 \mathrm{~cm})$ followed by Kuriftu $(24.53 \mathrm{~cm})$ [1]. This might be variation between the two environments.

\subsection{Bulb Diameter and Number of Cloves Per Bulb}

Significantly the highest bulb diameter was recorded from Tsedey $92(31.2 \mathrm{~mm})$ followed by Chelenko I $(27.46 \mathrm{~mm})$ while the lowest bulb diameter $(22.98 \mathrm{~mm})$ was recorded from local check. On the other hand the highest number of clove per bulb was recorded from local check (12.75) while the lowest from HL variety (8.36). This result is in line with [1] who reported that the highest number of cloves per bulb was recorded from local among tasted garlic varieties.

\subsection{Bulb Weight and Yield}

The current result showed that the bulb weight and yield were affected by the variety. Significantly the highest bulb weight $(26.18 \mathrm{~g})$ and yield $(8.45 \mathrm{t} / \mathrm{ha})$ were recorded from Tsedey 92 variety while the lowest bulb weight $(17.14 \mathrm{~g})$ and yield (4.34t/ha) from HL variety. The current result showed the possibility of bulb yield increment by $54.3 \%$ and $13.3 \%$ via use of Tsedey 92 variety over local and standard check (Chelenko I), respectively. However, overall yield was lower compared to the national average yield. Similarly, [12] reported that the maximum bulb weight $(26.07 \mathrm{~g})$ and yield $(8.067 \mathrm{t} / \mathrm{ha})$ recorded from Tsadey 92 as compared to five garlic varieties. However, this result varies from the study conducted by [1] reported that the highest tuber yield were recorded 16.16, 11.78 and 5.57t/ha from local, Kuriftu and Tsadey 92 varieties respectively. This might be variation between the two environments.

\section{Conclusion and Recommendation}

As indicated in the result there was significant differences among the varieties for all parameters, except days to maturity. Among the varieties, Tsedey 92 provided about $54.3 \%$ and $13.3 \%$ yield advantages over the local and standard check, respectively. Also Tsedey 92 was tolerant to rust disease than other varieties and local cultivar. Therefore, for sustainable garlic production and productivity in study area Tsedey 92 was recommended and need to be demonstrated.

\section{Acknowledgements}

The authors greatly indebted to acknowledge the Oromia Agricultural Research Institute for financing this research and Fedis Agricultural Research Centre to facilities and operate the research. Moreover, we acknowledge Murtesa Yusuf for their involvements in field data collection.

\section{References}

[1] Ayalew, A., Tadesse, D., Medhin, Z. G. and Fantaw, S. (2015) Evaluation of Garlic (Allium sativum L.) Varieties for Bulb Yield and Growth at Dabat, Northwestern Ethiopia. Open Access Library Journal, 2: e1216.

[2] CSA (Central Statistical Agency). The Federal Democratic Republic of Ethiopia Central Statistical Agency Agricultural Sample Survey, 2017/18 Volume I Report on area and production of major crops Addis Ababa, April, 2018

[3] FAOSTAT (Food and Agriculture Organization of the United Nations Statistics). (2011) http://faostat.fao.org/site/567/DesktopDefault.aspx?PageID=5 67\#ancor; 21/12/2013. 
[4] FAO 2015. Major Food and Agricultural Commodities and Producers Countries by Commodity. http://faostat.fao.org/site/567.

[5] Getachew, T., Asfaw, Z. 2010. Achievements in shallot and garlic research. Report No. 36. Ethiopian Agricultural Research Organization, Addis Ababa Ethiopia.

[6] Gomez KA, Gomez AA. Statistical procedures for agricultural research, 2nd edition, John Wiley and Sons, New York. 1984, 680.

[7] Higdon, J. (2005). Garlic and organosulfur compounds. Linus Pauling Institute, Macronutrient Information Center, Oregon State University. Retrieved from $\mathrm{http} / / /$ lpi.oregonstate.edu/mic/food-beverages/garlic

[8] Kibebew, 2014 characterization of Agricultural soils in cascape intervention woredas in Eastern region.

[9] Maly, I., Bartos, J., Hlusek, J., Kopec, K., Peteikova, K., Rod, J., Spitz, P. (1998). Polni zelina_stvi. Agrospoj Praha, 175-185.

[10] Ministry of Agriculture and Natural Resources, Plant Variety
Release, protection and seed quallty control directorate crop variety register issue No. 19 June, 2016 Addis Ababa, Ethiopia.

[11] Mohammed Amin, Shiberu Tadele and Thangavel Selvaraj. 2014. White rot (Scelerotium cipivorum Berk)-an aggressive pest of onion and garlic in Ethiopia: an overview. Journal of Agricultural Biotechnology \& Sustainable Development 6 (1): $6-15$.

[12] Tadese Teweldebrhan, 2009 Participatory varietal evaluation and faremer based seed production: A sustainable approach to garlic seed delivery in Atsbi Womberta Wereda, Eastern Tigray.

[13] Takele Tesgera, Fikru Regassa, Bulto Giro and Abdinur Mohammed (2017) Study on prevalence and identification of ixodid ticks in cattle in Gursum district, East Hararghe Zone of Oromia Regional State, Ethiopia. Journal of Parasitology and Vector Biology.

[14] Yadav RN, Bairwa HL, Gurjar MK (2017). Response of garlic (Allium sativum L.) to organic manures and fertilizers. International Journal of Current Microbiology and Applied Sciences 6 (10): 4860-4867. 